\title{
Optimization of $\mathbf{C} / \mathrm{N}$ Ratio and Inducers for Wastewater Paper Industry Treatment Using Trametes versicolor Immobilized in Bubble Column Reactor
}

\author{
Aura M. Pedroza-Rodríguez ${ }^{1}$ and Refugio Rodríguez-Vázquez ${ }^{2}$ \\ ${ }^{1}$ Grupo de Biotecnología Ambiental e Industrial, Departamento de Microbiología, Facultad de Ciencias, \\ Pontificia Universidad Javeriana, Carrera 7 No. 43-82, Bogotá, Colombia \\ ${ }^{2}$ Departamento de Biotecnología y Bioingeniería del Centro de Investigaciones y Estudios Avanzados del Instituto Politécnico Nacional, \\ CINVESTAV-IPN, Avenida Politécnico Nacional 2508, 0736 México, DF, Mexico \\ Correspondence should be addressed to Aura M. Pedroza-Rodríguez; apedroza@javeriana.edu.co
}

Received 30 August 2013; Accepted 6 November 2013

Academic Editor: Ángel Domínguez

Copyright (C) 2013 A. M. Pedroza-Rodríguez and R. Rodríguez-Vázquez. This is an open access article distributed under the Creative Commons Attribution License, which permits unrestricted use, distribution, and reproduction in any medium, provided the original work is properly cited.

\begin{abstract}
$\mathrm{C} / \mathrm{N}$ ratio and $\mathrm{MnSO}_{4}$ and $\mathrm{CuSO}_{4}$ concentrations were optimized for decolorization and chemical oxygen demand (COD) removal of bleached Kraft pulp mill effluent by Trametes versicolor immobilized in polyurethane foam. Statistical differences $(P<0.0001)$ at high $\mathrm{C} / \mathrm{N}$ ratios (169), $2 \mathrm{mM} \mathrm{CuSO}_{4}$, and $0.071 \mathrm{mM} \mathrm{MnSO}_{4}$ were determined. Decolorization of $60.5 \%$, COD removal of $55 \%$, laccase (LAC) $60 \mathrm{U} / \mathrm{L}$, and manganese peroxidase (MnP) 8.4 U/L were obtained. Maximum of decolorization (82\%), COD removal (83\%), LAC (443.5 U/L), and $\mathrm{MnP}(18 \mathrm{U} / \mathrm{L})$ activities at $\mathrm{C} / \mathrm{N}$ ratio of $405\left(6.75 \mathrm{mM} \mathrm{CuSO}_{4}\right.$ and $\left.0.22 \mathrm{mM} \mathrm{MnSO}_{4}\right)$ was achieved in step 7 at $4 \mathrm{~d}$. Positive correlation between the decolorization, COD removal, and enzymatic activity was found $(P<0.0001)$. T. versicolor bioremediation capacity was evaluated in bubble column reactor during $8 \mathrm{~d}$. Effluent was adjusted according to optimized parameters and treated at $25^{\circ} \mathrm{C}$ and air flow of $800 \mathrm{~mL} / \mathrm{min}$. Heterotrophic bacteria growth was not inhibited by fungus. After $4 \mathrm{~d}$, $82 \%$ of COD reduction and $80 \%$ decolorization were recorded. Additionally, enzymatic activity of LAC (345 U/L) and MnP (78 U/L) was observed. The COD reduction and decolorization correlated positively $(P<0.0001)$ with enzymatic activity. Chlorophenol removal was $98 \%$ of pentachlorophenol (PCP), $92 \%$ of 2,4,5-trichlorophenol (2,4,5-TCP), 90\% of 3,4-dichlorophenol (3,4-DCP), and $99 \%$ of 4 -chlorophenols (4CP).
\end{abstract}

\section{Introduction}

The paper industries generate significant quantities of wastewaters requiring around $15-60 \mathrm{~m}^{3}$ per ton of pulp produced. Wood and the sugarcane bagasse are the main raw materials for the process. Kraft pulp is commonly bleached with chlorine and its oxides, with an initial oxygen bleaching step. Of the different waste streams, bleaching plant effluents are the most toxic, due to the chlorinated organic compounds, color, and COD generated [1]. The brown color of wastewater is due to various conjugated structures including quinones, benzoquinones, complexed catechols, chalcones, and stilbenes, which absorb visible light $[2,3]$.

Biological treatment using white rot fungi such as T. versicolor involves multiple biochemical and physical reactions that can be carried out simultaneously, like the breakdown of intermolecular bonds, demethylation, hydroxylation, dechlorination, and the opening of the aromatic ring [4]. All of these transformations are developed together through the combined action of several enzymes, for example, laccase, manganese peroxidase, lignin peroxidase, xylanases, veratryl alcohol oxidase, and so forth $[5,6]$. Other mechanisms are related to physicochemical interactions such as adsorption, deposition, and ion exchange [7]. Several strategies have been successfully applied to enhance the efficiency of biological treatments including immobilization of the fungus in inert supports. This system has been shown to have more potential than the free cell because it reduces the problems of viscosity, oxygen transfer, and biomass recycling [8]. Several works had been made to assay different support, natural such as 
maple woodchips, jute twine, wheat straw, and stone and synthetic as polyurethane, nylon mesh reporting colonization of the support by fungi and dye decolorization $[9,10]$. Other alternatives consist on the supplementation of simple carbon sources that are used as a cosubstrate and addition of the inducers such as $\mathrm{MnSO}_{4}$ and $\mathrm{CuSO}_{4}$ to increase the levels of enzymatic activity MnP and Laccase [10-12]. Even though there are several reports related to the effect of these compounds, however, there are few reports about the effect of $\mathrm{C} / \mathrm{N}$ ratio, $\mathrm{Mn}$, and $\mathrm{Cu}$ on manganese peroxidase and laccase induction, during effluent decolorization under nonsterilized conditions.

The objective in this study was to evaluate the effect of the $\mathrm{C} / \mathrm{N}$ ratio and addition of $\mathrm{MnSO}_{4}$ and $\mathrm{CuSO}_{4}$, on $\mathrm{LAC}$ and $\mathrm{MnP}$ activity induction by $T$. versicolor immobilized in polyurethane foam (PUF) and to determine T. versicolor capacity for color, chlorophenols, and COD removal from a wastewaters of bleaching Kraft mill paper industry in bubble column reactor under nonsterilized conditions. The strategies used were a first-order design and the path of steepest ascent method for optimization of nutritional conditions in the effluents.

\section{Materials and Methods}

2.1. Microorganism. T. versicolor was used in this study. The fungus was maintained on mineral oil at $4^{\circ} \mathrm{C}$. For reactivation T. versicolor was grown in a wheat bran extract agar plates at $25^{\circ} \mathrm{C}$ for $8 \mathrm{~d}[13]$.

2.2. Immobilization of the Fungus. Polyurethane foam (PUF) cubes of $1 \mathrm{~cm}^{3}$ were used as the supporting matrix for immobilization of the fungus. The surface area was $450 \mathrm{~m}^{2} / \mathrm{m}^{3}$ with a density of $18 \mathrm{Kg} / \mathrm{m}^{3}$. Fifty cubes with ten agar plugs (8 days old) were inoculated in $500 \mathrm{~mL}$ Erlenmeyer flasks containing $200 \mathrm{~mL}$ of wheat bran extract medium [14]. After $9 \mathrm{~d}$ of incubation at $25^{\circ} \mathrm{C}$ and $120 \mathrm{rpm}$ in an orbital shaker the biomass immobilized in the support was passed in the wheat bran extract agar for $2 \mathrm{~d}$ at $25^{\circ} \mathrm{C}$. Then the cubes with abundant white mycelium were removal of the petri dishes and these biomaterials were inoculated into the reactors. For the experiments with the dead biomass, the cubes were sterilized at $121^{\circ} \mathrm{C}$ for $15 \mathrm{~min}$.

2.3. Scanning Electron Microscopy (SEM). Thin-sliced sections of the matrix were obtained in order to observe the mycelial growth in the PUF. The thin sections were prepared and fixed for $1 \mathrm{~h}$ with glutaraldehyde at $2.5 \%(\mathrm{v} / \mathrm{v})$ and were then washed with $0.1 \mathrm{M}$ phosphate buffer $(\mathrm{pH} 7.0)$ and fixed with osmium tetraoxide at $1 \%(\mathrm{v} / \mathrm{v})$ for $2 \mathrm{~h}$. The fixed particles were dehydrated using a series of ethanol washings with increasing ethanol concentration $(70,85,95$, and $100 \%$ $\mathrm{v} / \mathrm{v}$ ) for $5 \mathrm{~min}$. After $24 \mathrm{~h}$, the specimens were mounted on stainless steel stubs, coated immediately with gold in an ion coater, and examined using a Jeol-JSM-6300.

2.4. Effluent Characteristics. Effluent was provided by a pulp paper industry. $\mathrm{pH}$ of effluent was 8.5 , COD was $8000 \mathrm{mg} / \mathrm{L}$, $\mathrm{C} / \mathrm{N}$ ratio (10), and color unit was $5800,11.2 \mathrm{mg} / \mathrm{L} \mathrm{PCP}$,
$18 \mathrm{mg} / \mathrm{L}$ 2,4,5-TCP, $12.4 \mathrm{mg} / \mathrm{L}$ 3,4-DCP, $14 \mathrm{mg} / \mathrm{L} 4 \mathrm{CP}, 85 \times$ $10^{2} \mathrm{CFU} / \mathrm{mL}$ heterotrophic bacteria, and $10 \times 10^{2} \mathrm{CFU} / \mathrm{mL}$ heterotrophic yeast. The color of the effluent was measured according to the APHA, 2005. The COD was determined by the open reflux titration method [15]. The chlorophenols were analyzed by HPLC, according to the methodology of Ríos and Calva [16]. The changes in the microbial populations in the effluent without treatment and the effluent treated with $T$. versicolor were investigated. Colony forming units per milliliter $(\mathrm{CFU} / \mathrm{mL})$ were measurement used counts of microtechnique using PDA agar and nutrient agar for yeast and bacteria. Most abundant bacterial colonies were characterized by performing Gram stain and ten isolated colonies were grown in King B agar plates for $48 \mathrm{~h}$ at $37^{\circ} \mathrm{C}$. Then, they were examined under $(366 \pm 10) \mathrm{nm}$ ultraviolet light for $10 \mathrm{~s}$. The colonies that showed fluorescence were estimated as presumptive evidence of the presence of Pseudomonas spp.

2.5. Evaluation of Enzymatic Activity. The enzyme MnP (EC 1.11.1.13) was determined by the oxidation of phenol red $0.05 \%(\mathrm{w} / \mathrm{v})$, in succinic buffer $20 \mathrm{mM}, \mathrm{pH} 4.5$ [17]. LAC (EC 1.10.3.2) was determined through the oxidation of ABTS $0.5 \mathrm{mM}$ in sodium acetate buffer $100 \mathrm{mM}, \mathrm{pH} 4.5$ [18]. The enzymatic unit was defined as the formation of $1 \mu \mathrm{moL}$ of product per minute under the evaluated conditions.

\subsection{Experimental Design}

2.6.1. Factorial $2^{2}$ with Central Points Experimental Design. Complete factorial design (replicates and with central point), which takes into account all degrees of freedom, was used. The general form of this design is $2^{n}$, where $n$ is the number of factors (in this case ratio $\mathrm{C} / \mathrm{N}$ and inductor concentration) and 2 represents two levels of work. The levels are identified as low level $(-1)$, high level $(+1)$, and the central point $(0)$. The conditions of factorial design were $10 / 1$ and $169 / 1$ for $\mathrm{C} / \mathrm{N}$ ratio and $0.029 / 1 \mathrm{mM} \mathrm{MnSO}_{4} / \mathrm{mM} \mathrm{CuSO}_{4}$ and $0.071 / 2 \mathrm{mM}$ $\mathrm{MnSO}_{4} / \mathrm{mM} \mathrm{CuSO}_{4}$ for inductor concentration. These values were chosen based on previous results (data not show). The treatments and the results of the experimental design are shown in Tables 1(a) and 1(b).

A first-order experimental design was treated with an empirical model which relates the response measured to the independent factors of the experiment. For a two-factor system, the model is

$$
y=b_{o}+b_{1} x_{1}+b_{2} x_{2}+x_{1} x_{2}
$$

where $y$ corresponds to the predicted decolorization, COD removal, and enzyme activities (LAC and $\mathrm{MnP}$ ); $b_{o}$ is the intercept, $b_{1}, b_{2}$ are the linear coefficients, and $X_{1}, X_{2}$ are the factors. The evaluation of the coefficients determined the address in which the factors should move to obtain better results (Tables 2 and 3). The quality of the fitted model was evaluated analyzing the variance (ANOVA) and verifying if the model reproduces the experimental data in the studied range. The "Design Expert" (version 6.0) and "SAS" (version 5) software were used for analyses of the obtained data.

Experiments were carried out in $125 \mathrm{~mL}$ Erlenmeyer flasks containing $50 \mathrm{~mL}$ of the wastewater supplemented with 
TABLE 1: Values of real values and coded levels used in the factorial designs.

(a)

\begin{tabular}{|c|c|c|c|c|c|c|}
\hline Treatment & Factor $X_{1}$ & Factor $X_{2}$ & Decolorization (\%) & COD removal (\%) & Laccase volumetric activity (U/L) & $\begin{array}{l}\text { MnP volumetric } \\
\text { activity (U/L) }\end{array}$ \\
\hline 1 & -1 & -1 & 7.24 & 10.26 & 0 & 0.3 \\
\hline 2 & +1 & -1 & 20.13 & 72.47 & 23.08 & 1.57 \\
\hline 3 & -1 & +1 & 10.57 & 15.60 & 0 & 0.89 \\
\hline 4 & +1 & +1 & 60.36 & 51.40 & 60.36 & 8.64 \\
\hline 5 & 0 & 0 & 55.97 & 19.05 & 44.67 & 0.16 \\
\hline 6 & 0 & 0 & 57.14 & 23.81 & 48.04 & 0.13 \\
\hline 7 & 0 & 0 & 59.20 & 18.18 & 44.5 & 1.6 \\
\hline
\end{tabular}

Numeric value equivalent to the code level $(-1),(+1) y(0)$.

(b)

\begin{tabular}{|c|c|c|}
\hline Factor level & $\mathrm{C} / \mathrm{N}$ ratio $\left(X_{1}\right)$ & $\begin{array}{l}\text { Inductor concentration } \\
\left(X_{2}\right) \\
\mathrm{mM} \mathrm{MnSO}_{4} / \mathrm{mMCuSO}_{4}\end{array}$ \\
\hline Lower level & $10 / 1$ & $0.029 / 1$ \\
\hline Upper level & $169 / 1$ & $0.071 / 2$ \\
\hline Central point & $90 / 1$ & $0.05 / 1.5$ \\
\hline
\end{tabular}

TABLE 2: ANOVA results, model and coefficient validation for decolorization and COD removal in percentage.

\begin{tabular}{|c|c|c|c|c|c|c|c|c|c|c|c|c|}
\hline \multirow{3}{*}{ Factor } & \multicolumn{6}{|c|}{ Decolorization } & \multicolumn{6}{|c|}{ Chemical oxygen demand } \\
\hline & \multicolumn{6}{|c|}{ Percentage } & \multicolumn{6}{|c|}{ COD removal (\%) } \\
\hline & SS & DF & MS & $F$ value & Prob $>F$ & $\mathrm{RC}$ & SS & DF & MS & $F$ value & Prob $>F$ & RC \\
\hline Model & 5390.19 & 3 & 1796.7 & 215.62 & $<0.0001$ & 24.57 & 7914.67 & 3 & 2638.22 & 113.46 & $<0.0001$ & 37.43 \\
\hline$X_{1}$ & 2946.13 & 1 & 2946.1 & 353.56 & $<0.0001$ & 15.67 & 7205.92 & 1 & 7205.92 & 309.89 & $<0.0001$ & 24.50 \\
\hline$X_{2}$ & 1422.90 & 1 & 1422.9 & 170.76 & $<0.0001$ & 10.89 & 185.54 & 1 & 185.54 & 7.98 & 0.0180 & -3.93 \\
\hline$X_{1} X_{2}$ & 1021.16 & 1 & 1021.1 & 122.55 & $<0.0001$ & 9.22 & 523.20 & 1 & 523.20 & 22.50 & 0.0008 & -6.60 \\
\hline Curvature & 2596.72 & 1 & 2596.7 & 311.63 & $<0.0001$ & & 700.64 & 1 & 700.64 & 30.13 & 0.0003 & \\
\hline Pure error & 83.33 & 10 & 8.33 & & & & 232.53 & 10 & & & & \\
\hline Cor total & 8070.23 & 14 & & & & & 8847.83 & 14 & & & & \\
\hline \multicolumn{2}{|c|}{$\mathrm{CV}$} & \multicolumn{5}{|c|}{9.27} & \multicolumn{2}{|c|}{$\mathrm{CV}$} & \multicolumn{4}{|c|}{14.18} \\
\hline \multicolumn{2}{|c|}{$R^{2}$} & \multicolumn{5}{|c|}{0.9802} & & & \multicolumn{4}{|c|}{0.9629} \\
\hline \multicolumn{2}{|c|}{ Adeq Precision } & \multicolumn{5}{|c|}{31.871} & \multicolumn{2}{|c|}{ Adeq Precision } & \multicolumn{4}{|c|}{22.347} \\
\hline
\end{tabular}

different glucose and inducer concentration (according to experimental design). A total of ten cubes colonized with the fungus were inoculated and Erlenmeyer flasks were continuously shaken at $120 \mathrm{rpm}$ for $4 \mathrm{~d}$ at $25^{\circ} \mathrm{C}$. Control was carried out with the same number of Erlenmeyer flasks but inoculated with cubes colonized by fungal biomass inactivated with thermal treatment at $121^{\circ} \mathrm{C}$ for $30 \mathrm{~min}$.

2.6.2. Optimization of Factors with the Path of Steepest Ascent Method. After the first-order experimental design was established, the concentration factors were optimization with the path of steepest ascent method. The selected value of origin was the $\mathrm{C} / \mathrm{N}$ ratio and inducer concentrations used in the $2^{2}$ factorial designs (C/N ratio: $90 / 1$ with $5.5 \mathrm{~g} / \mathrm{L}$ glucose to obtain $90 / 1 \mathrm{C} / \mathrm{N}$ ratio, $0.05 \mathrm{mM} \mathrm{MnSO}_{4}$, and $1.5 \mathrm{mM} \mathrm{CuSO}_{4}$ ). The delta selected to calculate the different ascents was 0.5 (C/N: $45,0.025 \mathrm{mM}$ of $\mathrm{MnSO}_{4}$, and $0.75 \mathrm{mM}$ of $\mathrm{CuSO}_{4}$ ), the increased of ratio $\mathrm{C} / \mathrm{N}$ was make for addition of glucose into effluent according to optimization methods reported by Montgomery [19]. Experiments and controls were carried out in same form to use in design factorial and the parameters were evaluated on the $4 \mathrm{~d}$ (Table 4 ).

2.7. Biological Reactor and Operational Conditions. The biological treatment was performed in reactors made up of glass tubing (6 cm inner diameter, $50 \mathrm{~cm}$ long) packed with 160 polyurethane foam cubes colonized with $T$. versicolor and $800 \mathrm{~mL}$ of nonsterilized bleaching effluent, supplemented with glucose up to a $\mathrm{C} / \mathrm{N}$ ratio of 405 (glucose concentration $25 \mathrm{~g} / \mathrm{L})$ and inducers $\left(6.75 \mathrm{mM} \mathrm{CuSO}_{4}\right.$ for LAC activity and $0.22 \mathrm{mM} \mathrm{MnSO}_{4}$ for $\mathrm{MnP}$ activity). The reactors were maintained at $25^{\circ} \mathrm{C}$, with an air flow rate of $800 \mathrm{~mL} / \mathrm{min}$ (Figure 1). The process was evaluated over $8 \mathrm{~d}$. The values in the figures correspond to the mean values of three replicates with a standard deviation of less than $20 \%$. 
TABLE 3: ANOVA results, model and coefficient validation for laccase an MnP volumetric activities.

\begin{tabular}{|c|c|c|c|c|c|c|c|c|c|c|c|c|}
\hline \multirow{2}{*}{ Factor } & \multicolumn{6}{|c|}{ Laccase volumetric activity (U/L) } & \multicolumn{6}{|c|}{$\mathrm{MnP}$ volumetric activity (U/L) } \\
\hline & SS & DF & MS & $F$ value & Prob $>F$ & $\mathrm{RC}$ & SS & DF & MS & $F$ value & Prob $>F$ & $\mathrm{RC}$ \\
\hline Model & 7305.25 & 3 & 2435.0 & 237.19 & $<0.0001$ & 20.86 & 136.50 & 3 & 45.50 & 72.22 & $<0.0001$ & 2.85 \\
\hline$X_{1}$ & 5220.55 & 1 & 5220.5 & 508.50 & $<0.0001$ & 20.86 & 61.05 & 1 & 61.05 & 96.90 & $<0.0001$ & 2.26 \\
\hline$X_{2}$ & 1042.35 & 1 & 1042.3 & 101.53 & $<0.0001$ & 9.32 & 43.95 & 1 & 43.95 & 69.77 & $<0.0001$ & 1.91 \\
\hline$X_{1} X_{2}$ & 1042.35 & 1 & 1042.3 & 101.53 & $<0.0001$ & 9.32 & 31.50 & 1 & 31.50 & 50.00 & $<0.0001$ & 1.62 \\
\hline Curvature & 1487.34 & 1 & 1487.3 & 144.87 & $<0.0001$ & & 11.81 & 1 & 11.81 & 18.74 & 0.0015 & \\
\hline Pure error & 102.67 & 10 & 10.27 & & & & 6.30 & 10 & 0.63 & & & \\
\hline Cor total & 8895.25 & 14 & & & & & 154.61 & 14 & & & & \\
\hline \multicolumn{2}{|c|}{$\mathrm{CV}$} & \multicolumn{5}{|c|}{12.40} & \multicolumn{2}{|c|}{ CV } & \multicolumn{4}{|c|}{0.9426} \\
\hline \multicolumn{2}{|c|}{$R^{2}$} & \multicolumn{5}{|c|}{0.9820} & & & \multicolumn{4}{|c|}{33.01} \\
\hline \multicolumn{2}{|c|}{ Adeq Precision } & \multicolumn{5}{|c|}{32.626} & \multicolumn{2}{|c|}{ Adeq Precision } & \multicolumn{4}{|c|}{18.196} \\
\hline
\end{tabular}

TABLE 4: Path of steepest ascent, experimental design.

\begin{tabular}{lcc}
\hline Ascent & Factor $X_{1} \mathrm{C} / \mathrm{N}$ ratio & $\begin{array}{c}\text { Factor } X_{2} \\
\text { Inducer Concentration } \\
\mathrm{mMnSO}_{4} / \mathrm{mM} \mathrm{CuSO}_{4}\end{array}$ \\
\hline Origin & $90 / 1$ & $0.05 / 1.5$ \\
Delta 0.5 & $45 / 1$ & $0.025 / 0.75$ \\
Origin $+1 \Delta$ & $135 / 1$ & $0.075 / 2.25$ \\
Origin $+2 \Delta$ & $180 / 1$ & $0.1 / 3$ \\
Origin $+3 \Delta$ & $225 / 1$ & $0.12 / 3.75$ \\
Origin $+4 \Delta$ & $270 / 1$ & $0.15 / 4.5$ \\
Origin $+5 \Delta$ & $315 / 1$ & $0.17 / 5.25$ \\
Origin $+6 \Delta$ & $360 / 1$ & $0.20 / 6.0$ \\
Origin $+7 \Delta$ & $405 / 1$ & $0.22 / 6.75$ \\
Origin $+8 \Delta$ & $450 / 1$ & $0.25 / 7.5$ \\
Origin $+9 \Delta$ & $495 / 1$ & $0.27 / 8.25$ \\
Origin $+10 \Delta$ & $540 / 1$ & $0.30 / 9.0$ \\
Origin $+11 \Delta$ & $585 / 1$ & $0.32 / 9.75$ \\
Origin $+12 \Delta$ & $630 / 1$ & $0.35 / 10.5$ \\
\hline
\end{tabular}

\section{Results and Discussion}

3.1. Scanning Electron Microscopy of Fungal Colonization in the Support. Polyurethane foam was used as inert matrix to favor the penetration of the fungus. This material has a surface area of $450 \mathrm{~m}^{2} / \mathrm{m}^{3}$ and density of $18 \mathrm{Kg} / \mathrm{m}^{3}$. Probably these characteristics favored the colonization process reaching a maximum biomass per cube of $93 \mathrm{mg} / \mathrm{cm}^{3}$ at $9 \mathrm{~d}$. On the other hand, we observed by SEM that the colonization of the fungal biomass was inside the foam and an extensive mycelium network was recovered completely from the PUF surface (Figures 2(a) and 2(b)). In some sections of the PUF were also observed other microorganisms that were from the wastewater as Gram-negative bacilli and yeast (Figures 2(c) and 2(d)). These Gram-negative bacilli produced blue fluorescence and cytochrome C oxidases (oxidase test); these results suggest the presence of Pseudomonas spp. into wastewater. Pseudomonas spp. is a bacterium widely distributed in nature and produces multicomponent enzyme

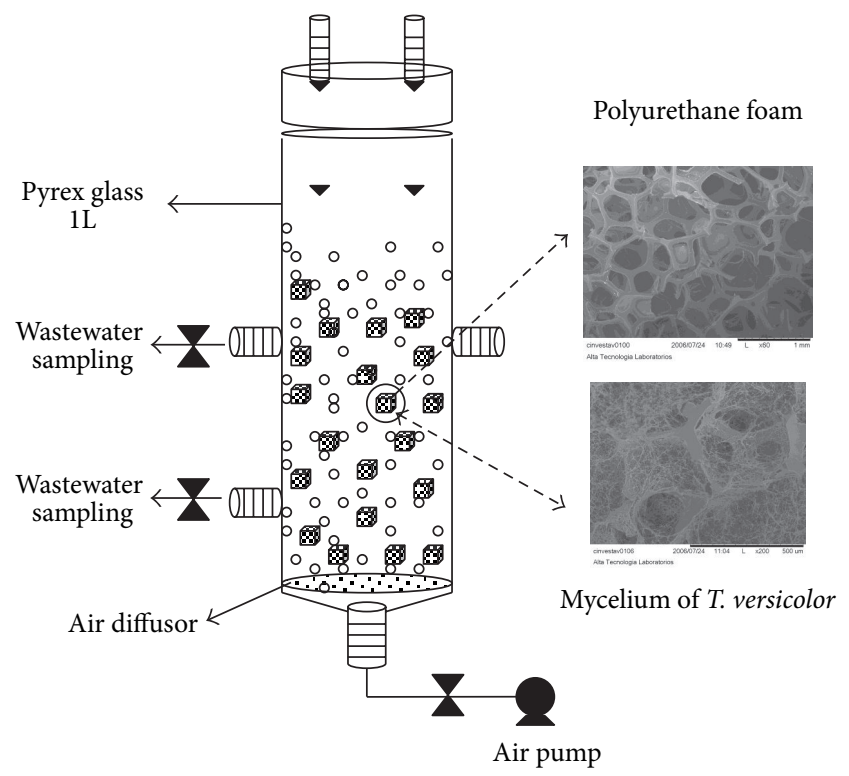

FIGURE 1: Bubble column reactor with polyurethane foam cubes colonized with $T$. versicolor.

systems (mono- and di-oxygenase) that add one or two oxygen to the aromatic nucleos to form arene cis-diol. With these enzymes Pseudomonas spp. could biotransform some lignin byproducts and participates in the color and COD removal. Activities that could be done in cooperation with the yeast and Trametes versicolor could be immobilized into PUF support. A similar result were found for Tiku et al.. In their research Pseudomonas sp. and Bacillus megaterium were recovered from pulp and paper mill effluents, and its ability to remove COD and BOD was demonstrated [20].

3.2. Experimental Design for Decolorization by T. versicolor. The main effects of the two factors studied and the binary interaction effect involving these factors are shown in Tables 2 and 3. The effects that presented statistical influence, for a level of confidence of $95 \%$, on the dependent variable (decolorization, COD removal, and LAC and MnP activities), are $\mathrm{C} / \mathrm{N}$ ratio, inductor concentration, and their interaction inside the range of the experimental studies. 


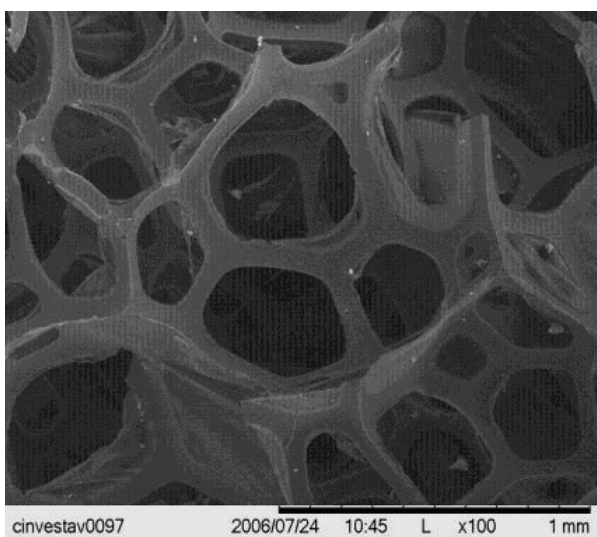

(a)

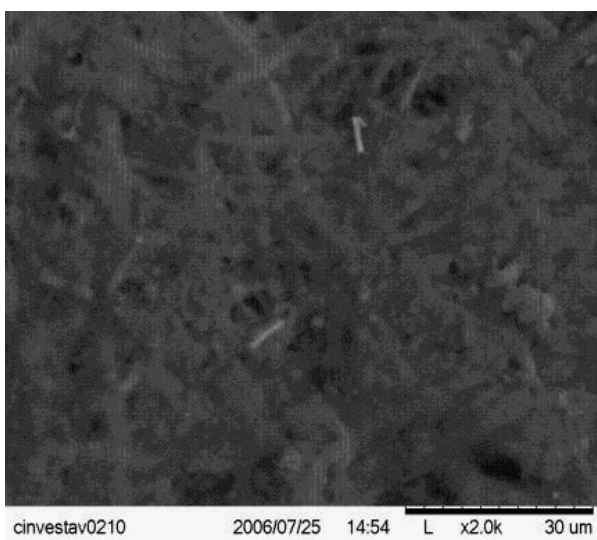

(c)

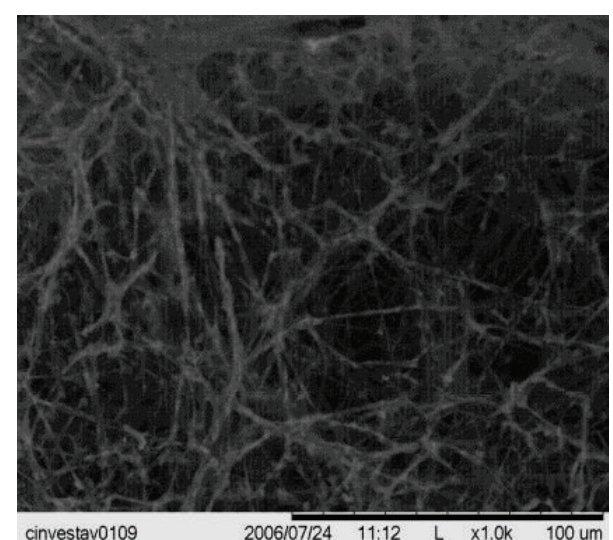

(b)

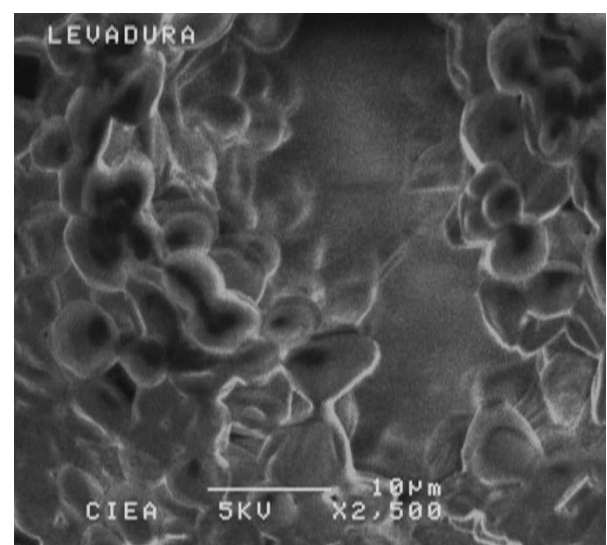

(d)

FIGURE 2: SEM microphotographs of polyurethane foam without colonization 100x (a). Polyurethane foam colonized with T. versicolor at $24 \mathrm{~h}$ of incubation 1000x (b). Mycelium of T. versicolor and Gram-negative Bacilli at $72 \mathrm{~h}$ of incubation 2000x (c). Yeast cells into the support at $72 \mathrm{~h} 2500 \mathrm{x}$ in bubble column reactor.

Analysis of variance (ANOVA) showed that $X_{1}$ factor, $X_{2}$ factor and their interaction $X_{1} X_{2}$ (high $\mathrm{C} / \mathrm{N}$ ratio (169), and inductor concentration $\left(0.071 \mathrm{mM} \mathrm{MnSO}_{4} / 2 \mathrm{mM} \mathrm{CuSO}_{4}\right)$ ) have a significant effect on decolorization, COD removal, and enzyme production. The values of the regression coefficients from the $2^{2}$ factorial experimental design with central points (Tables 2 and 3 ) were calculated, and the first-order equations for decolorization, COD removal, and LAC and MnP activity (2), (3), (4), and (5) are shown:

Decolorization $(\%)(y)$

$$
=24.5+15.66 x_{1}+10.88 x_{2}+9.21 x_{1} x_{2},
$$

COD removal $(\%)(y)=37+24 x_{1}-3.93 x_{2}-6.6 x_{1} x_{2}$,

Laccase activity $\mathrm{U} / \mathrm{L}(y)$

$$
=20.81+20.86 x_{1}+9.32 x_{2}+9.32 x_{1} x_{2},
$$

$\mathrm{MnP}$ activity $\mathrm{U} / \mathrm{L}(y)=2.85+2.26 x_{1}+1.91 x_{2}+1.62 x_{1} x_{2}$.
According to (2), (4), and (5), an increase in the concentration of the respective factors should have a positive effect for the dependent variables. However, the most influential factor was the $\mathrm{C} / \mathrm{N}$ ratio ( $X_{1}$ factor) with linear coefficients value of 15.6 , $24,20.86$, and 2.26 for decolorization, COD removal, laccase, and $\mathrm{MnP}$ activities. These results suggest that Trametes versicolor increased the removal capacity and enzyme activities when de $\mathrm{C} / \mathrm{N}$ ratio increases (ligninolytic conditions). For this reason the best results were obtained when the wastewater was supplemented with high concentration of glucose as simple carbon source (treatments 2 and 4); in contrast when the supplement with glucose were low (treatments 1 and 3), the removal and laccase activity were lower than T2 and T4. These results could be related to the production of proteolytic enzymes that cleave the ligninolytic enzymes when fungi have a deficit or low concentrations of carbon and nitrogen.

3.3. Optimization of Factors with the Path of Steepest Ascent Method. In this study we only used the first-order equation obtained for decolorization to optimization process using the path of steepest ascent methodology. The experimental results showed that, as the coefficient of the factors was increased, a positive effect was observed $(P<0.0001)$ on 


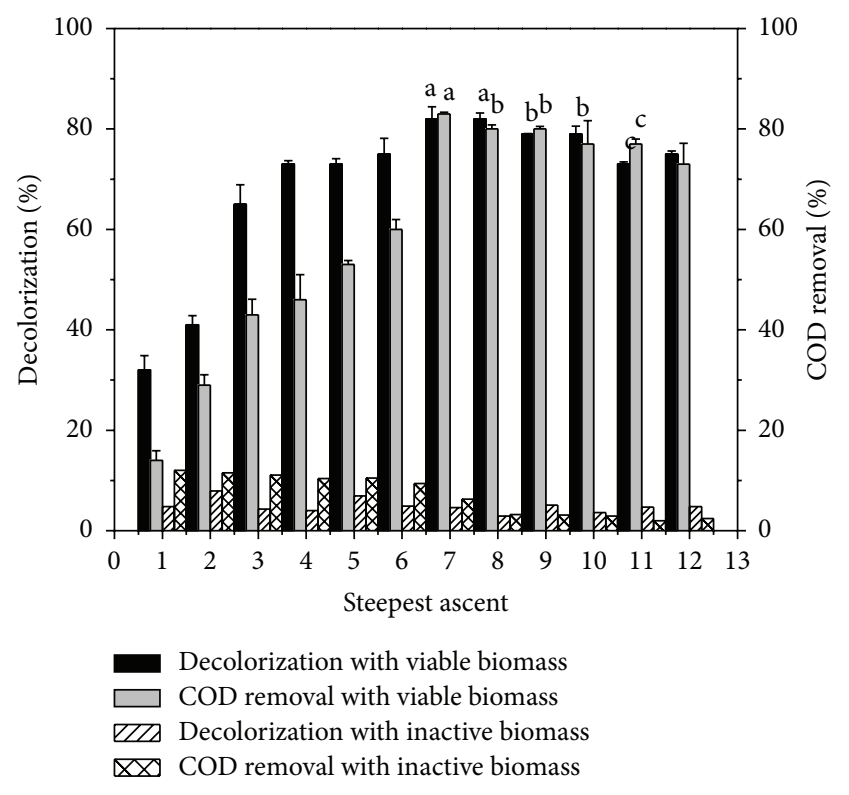

FIgURE 3: Decolorization and COD removal by T. versicolor in the path of steepest ascent method. $4 \mathrm{~d}, 120 \mathrm{rpm}$, and $25^{\circ} \mathrm{C}$.

the dependent variables. The maximum values of $82 \%, 83 \%$, $443 \mathrm{U} / \mathrm{L}$, and $18 \mathrm{U} / \mathrm{L}$, for color removal, COD removal, and LAC and MnP enzyme activities, respectively, were obtained (Figure 3). The highest value was obtained in step $7(\mathrm{C} / \mathrm{N}$ ratio 405 and inducer concentrations $0.22 \mathrm{mM} \mathrm{MnSO}_{4}$ and $\left.6.75 \mathrm{mM} \mathrm{CuSO}_{4}\right)$, with a positive correlation $(P<0.0001)$ between decolorization and COD removal in this step. These results could indicate that the organic compounds such as quinones and stilbenes were degraded and their capacity to absorb light were progressively decreased [3]. On the other hand the requirement for a second carbon source during paper industry wastewater degradation by different white rot fungi has been widely reported by Kaushik and Malik, Elisashvili and Kachlishvili, and Justino et al. [2123]. In these works it was shown that degradation capacity of Basidiomycetes increased when Kraft effluents were supplemented with a less-complex carbon source, such as glucose. These results agree with those reported by Belém et al. [2], who used two white rot fungi (Pleurotus sajor caju and Pleurotus ostreatus) for the wastewater treatment, finding that as the concentration increased in a simple cosubstrate (glucose), the efficiency in the COD removal and absorbance reduction for several wave lengths increased at 14 days of incubation. However further experiments are needed to determine other carbon sources, which may allow a more efficient decolorization and COD removal from a technical and economic point of view. The glucose was a suitable carbon source to determine the optimization model but is expensive for environmental applications using reactor with major capacity.

The correlation between decolorization, COD removal, and enzymatic activity, LAC and MnP, was less $(P>0.0001)$. This result could be justified in terms that the capacity of bioremediation of these microorganisms is associated with biochemical processes and physical-chemical parameters such as biosorption, deposition, and ionic exchange with components of the cellular wall, like chitin and chitosan [10-25]. For these reasons the removal can be development for both mechanism and the correlation with the enzymes was different with respect to the decolorization and COD removal. In the controls it was determined $10 \%$ of decolorization and $15 \%$ of COD removal indicating that dead biomass and the support could be adsorbed color and organic matter.

When analyzing the effect of the inducers on the enzymatic activity in step 7, one can observe a significant difference $(P<0.0001)$ between the production of LAC (Figure 4(a)) and MnP (Figure 4(b)) with respect to others steps. Youshuang et al. [26] demonstrated that T. versicolor is producing a thermostable metal-tolerant laccase and this enzyme showed good decolorization of triphenylmethane and azo dyes in the experiments without mediators.

The enzymatic laccase activity increased when copper is present in the culture medium. It has been postulated by Guillén and Machuca and Rivera-Hoyos et al. [27, 28]. These authors suggest that manganese and copper regulate $m n p$ gene transcription via a multicomponent system, perhaps involving signal receptors, a transducer, and an intercellular second messenger, such as cyclic AMP or a phosphorylation cascade, similar to the mechanism of metalloregulation in others eukaryotes. On the other hand, Álvarez et al. studied the effect of copper on the expression of genes encoding the ligninolytic enzymes, laccase (lcs) and manganese peroxidase $(m n p)$ in Ceriporiopsis subvermispora. They showed that this metal increased transcript levels of $l c s, m n p 1$, and $m n p 2$, and they isolated and characterized an ACE-1 like transcription factor from C. subvermispora (Cs-ACE1) essential to laccase induction with copper addition [29].

In our study the induction by heavy metals only was observed at concentrations of $6.75 \mathrm{mM}$ copper and $0.22 \mathrm{mM}$ manganese. Above these values these metals had a toxic effect on T. versicolor growth, and a decrease in the enzyme activity was observed (data not show). The mechanism by which T. versicolor is active at high concentrations of metals is associated with two phases. The first is independent of the metabolism and concerns the sorption of the metal to the cellular wall, while the second is dependent on the energy [30]. The sorption of significant quantities of the metal to the fungal cell wall is a rapid process, which is visualized by the pigmentation of the mycelium. These pigments (melanin, polymers of L-DOPA, catechol, glutaminyl-3, 4 dihydroxybenzene and 1 , and 8 dihydroxynaphthalene) were produced for LAC enzyme [31]. Copper-tolerant fungi produce oxalate which precipitates the metals in the form of $\mathrm{Cu}$-oxalate crystals. This mechanism could be acting in our case since, with a $\mathrm{C} / \mathrm{N}$ ratio of 405 Trametes sp. produced organics acid which led to a decrease in the $\mathrm{pH}$ to 4.1. This value is within the range reported for the two enzymes (between 4.0 and 4.5).

3.4. Biological Treatment in Bubble Column Reactor. In this study T. versicolor, under nonsterile conditions, decreased the color during the first $24 \mathrm{~h}$, and a level of $80.1 \%$ decolorization was attained by $4 \mathrm{~d}$ (Figure 5(a)). The mechanisms 


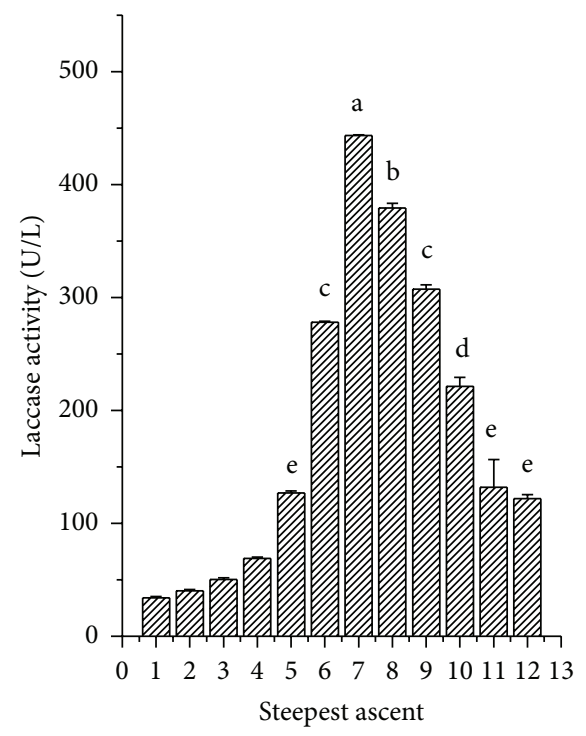

(a)

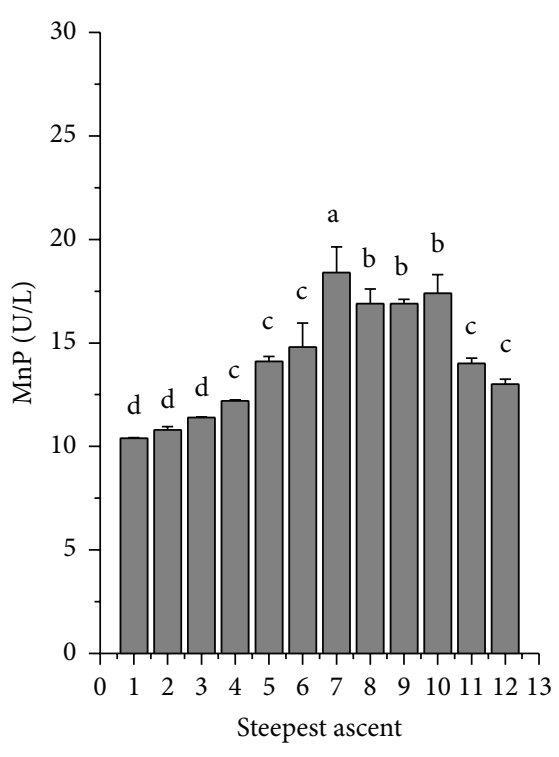

(b)

FIGURE 4: Enzyme activity during treatment with T. versicolor in the path of steepest ascent method, $4 \mathrm{~d}, 120 \mathrm{rpm}$, and $25^{\circ} \mathrm{C}$. LAC activity (a) and MnP activity (b).

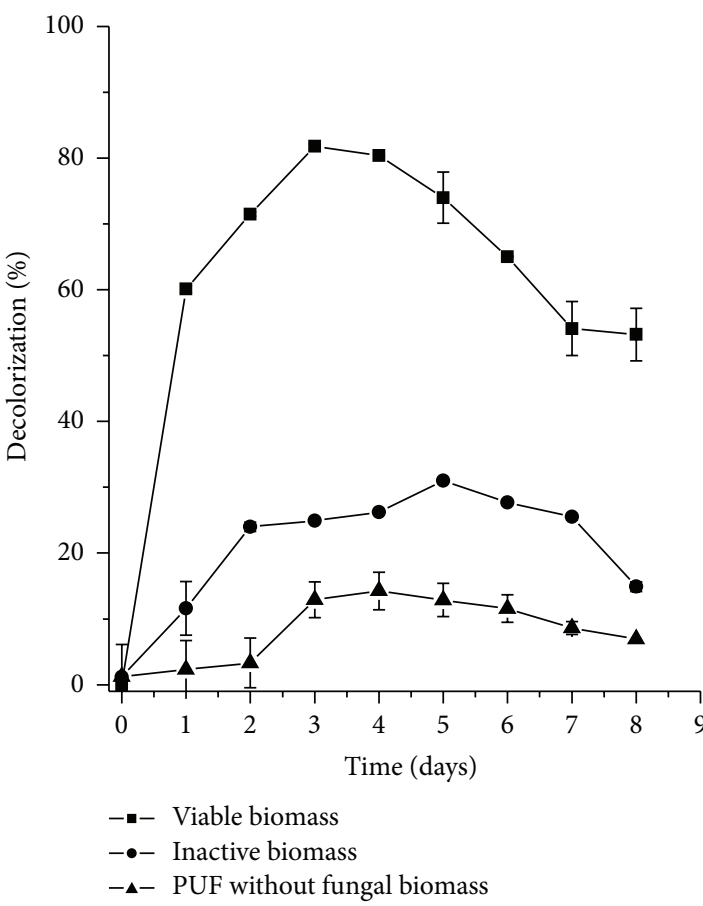

(a)

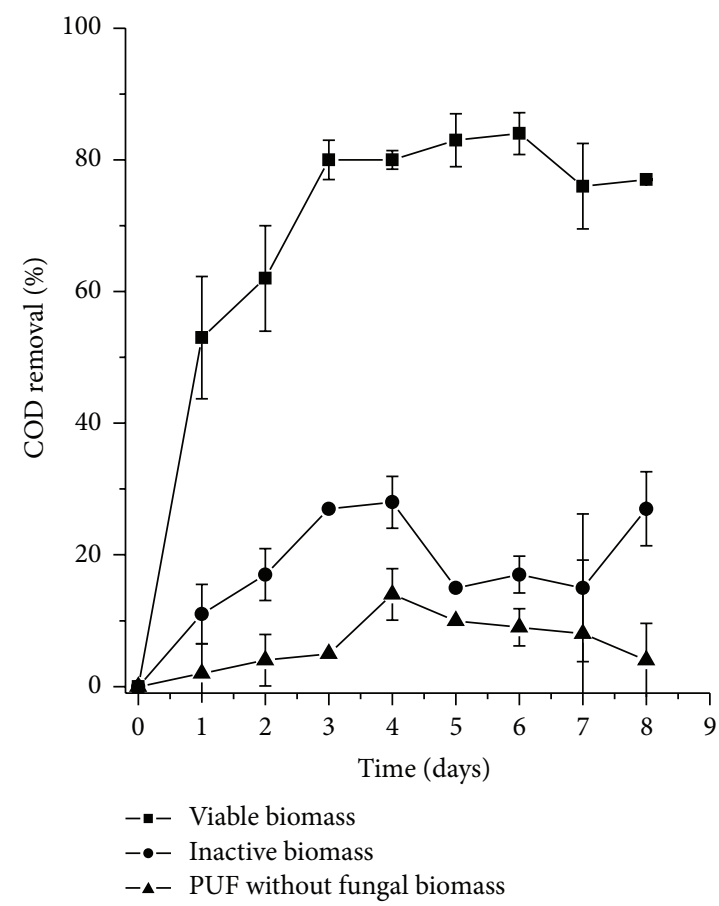

(b)

Figure 5: Biologic treatment with immobilized T. versicolor, $8 \mathrm{~d}, 25^{\circ} \mathrm{C}, 800 \mathrm{~mL} / \mathrm{min}$ flow air, and nonsterile conditions in bubble column reactor. Decolorization (a) and COD removal (b).

involved in the decolorization could be associated with physical adsorption followed by a biochemical mechanism. The first mechanism is not associated with metabolism but implies a biosorption through the formation of hydrophilichydrophobic interactions between the compound and the cell wall [25]. The second mechanism is associated with primary metabolism, in which the fungus uses a cosubstrate, like glucose, to degrade the most toxic compounds and to allow the color reduction $[10,32]$. The decolorization could be carried out by oxidation (via removal of one or two electrons) 


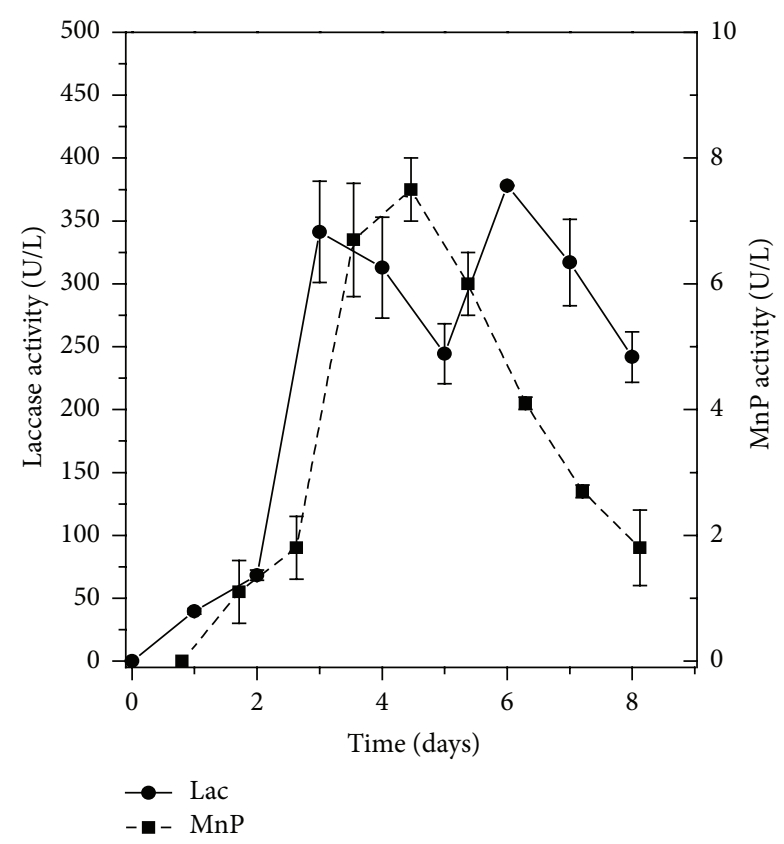

FIGURE 6: Enzymatic activity with immobilized T. versicolor. LAC activity (a), MnP activity (b), $8 \mathrm{~d}, 25^{\circ} \mathrm{C}, 800 \mathrm{~mL} / \mathrm{min}$ flow air, and nonsterile conditions in bubble column reactor.

of the recalcitrant chromophoric groups of the lignin to form radical cationic species that can follow different degradation routes [32-34]. During this study enzymatic activity was observed to increase progressively until it reached maximum values between days 4 and 5 of $345 \mathrm{U} / \mathrm{L} \mathrm{LAC}$ and $78 \mathrm{U} / \mathrm{L} \mathrm{MnP}$ (Figures 6(a) and 6(b)). Statistically a correlation $(P<$ 0.0001 ) exists between the percentage of decolorization, $\mathrm{COD}$ reduction, and enzymatic activity.

The results obtained are interesting, since the fungus carries out the bioremediation process of the wastewater from the pulping industry without requiring sterile conditions, reaching a high (80\%) colour removal in $96 \mathrm{~h}$ with $25 \mathrm{~g} / \mathrm{L}$ glucose as cosubstrate at acid $\mathrm{pH}$ (Figures 7(a) and 7(b)). In comparison, Sahoo and Gupta reported 60\% decolorization of effluent at $72 \mathrm{~h}$ with a supplement of $20 \mathrm{~g} / \mathrm{L}$ glucose using free cells of $T$. versicolor but under sterile conditions [35].

With regards to the reduction of the COD, the initial concentration was $50400 \mathrm{mg} / \mathrm{L}$, and this progressively diminished, attaining $82 \%$ of up-to-date removal with a positive correlation (Figure 5(b)) between percentage of COD reduction and chlorophenols $(P<0.0001)$. Rocha-Santos et al. demonstrated that the biomass of different white rot fungi and Rhizopus oryzae can be used for the organic compounds removal (carboxylic acids, fatty alcohols, phenolic compounds, and sterols) present in Kraft pulp mill effluent [36]. We found similar results with glucose as a source of carbon, low nitrogen concentration, copper and manganese addition, and acidic $\mathrm{pH}$.

With respect to the quantified chlorophenols, we observed during the biological treatment that removal started in the first $24 \mathrm{~h}$ with the biosorption processes and further degradation of the organic compounds. Maximum removal was attained after $4 \mathrm{~d}$ with $98 \%$ of PCP, $92 \%$ of $2,4,5-\mathrm{TCP}, 90 \%$ of $3,4-\mathrm{DCP}$, and $99 \%$ of $4 \mathrm{CP}$ (Figure 8 ). The latter was possibly generated by the dechlorination of highly chlorinated compounds like pentachlorophenol and tetrachlorophenol. A positive correlation $(P<0.0001)$ between COD reduction, decolorization, chlorophenol removal, and LAC activity was obtained (Figure 6(a)).

The removal of chlorophenols may be associated with a cometabolism process, and it becomes more efficient in the presence of a simple cosubstrate. The use of fermentable sugar allows a decrease in $\mathrm{pH}$ up to 4.1 (Figure 7(b)). A similar behavior was observed by Ulla, who used Coriolus versicolor for PCP removal and found that $\mathrm{pH} 5.0$ was associated with glucose consumption and a greater removal (90\%) was obtained, showing a strong correlation with the levels of LAC expression [37]. The enzymatic degradation of aromatic chlorinated compounds starts with an oxidative dechlorination due to the LACs, resulting in the formation of p-quinone (2,6-dichloro-1,4-quinone or tetrachlorobenzoquinone) or cationic radicals that result in a further dechlorination, which could occur via a nucleophilic attack on a molecule of water, producing chloroquinones [38]. These compounds are strong oxidizers and can be transformed into the corresponding hydroxyquinones, eliminating the atoms of chlorine completely, so that the ring opens upon the action of $\mathrm{MnP}$ and LAC to form sour beta intermediary ketoadipic acid that enters into the Krebs cycle [39].

When using the biological reactor without sterilizing the wastewater, the bacteria $\left(12 \times 10^{2} \mathrm{CFU} / \mathrm{mL}\right)$ and fungi $(23 \times$ $10^{2} \mathrm{CFU} / \mathrm{mL}$ ) present in them increased progressively until we obtained recounts of $50 \times 10^{7} \mathrm{CFU} / \mathrm{mL}$ for heterotrophic bacteria and $34 \times 10^{6} \mathrm{CFU} / \mathrm{mL}$ for heterotrophic fungi. A positive cooperation was possible between T. versicolor (biomass per cube of $193 \pm 5.3 \mathrm{mg} / \mathrm{cm}^{3}$ at $8 \mathrm{~d}$ ) and the other microorganisms. This situation is very favorable since the system could be used in reactors of higher capacity without the need to control the sterility. This diminishes the risk of losing efficiency due to the inhibition or death of the Basidiomycete.

\section{Conclusions}

Finally under laboratory conditions, the decolorization and COD removal in paper industry wastewater using T. versicolor were successfully optimized using a $2^{2}$ factorial experimental design with central points and a steepest ascent method. A high $\mathrm{C} / \mathrm{N}$ ratio together with the addition of millimolar amounts of $\mathrm{CuSO}_{4}$ and $\mathrm{MnSO}_{4}$ to the actively growing $T$. versicolor cultures offers an easy and efficacious method for stimulating color, COD, chlorophenols removal, and in minor proportion LAC and MnP activity. This represents an attractive way to stimulate pollutants removal partial associated with enzyme production and adsorption process.

The fungus T. versicolor interacted with bacteria and yeasts $\left(50 \times 10^{7} \mathrm{CFU} / \mathrm{L}\right.$ heterothophic bacteria, $34 \times$ $10^{6} \mathrm{CFU} / \mathrm{mL}$ of heterotrophic fungi) diminishing the color (1147 UC), COD (10400 mg/L), and chlorophenols in $4 \mathrm{~d}$ in bubble column reactor. 


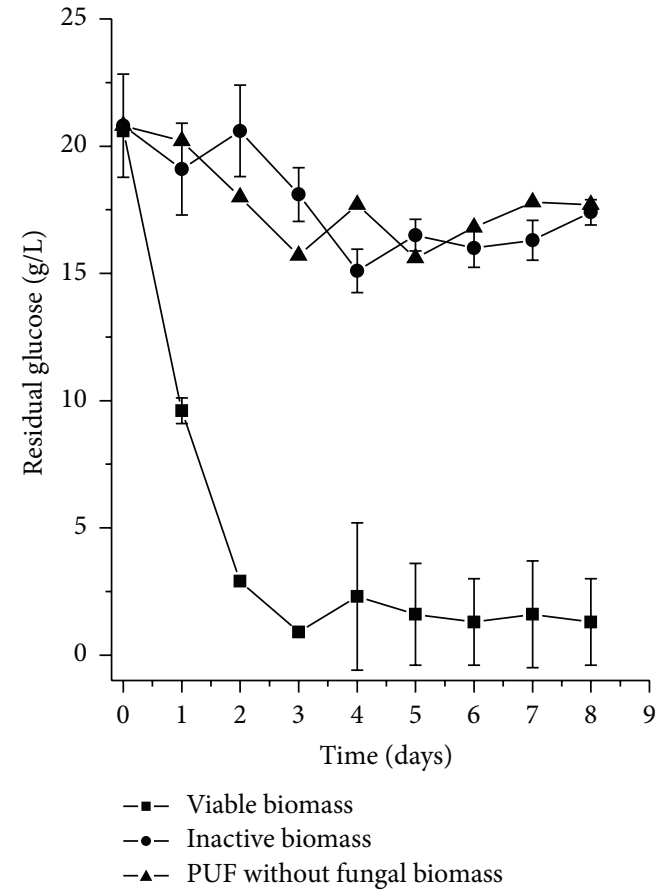

(a)

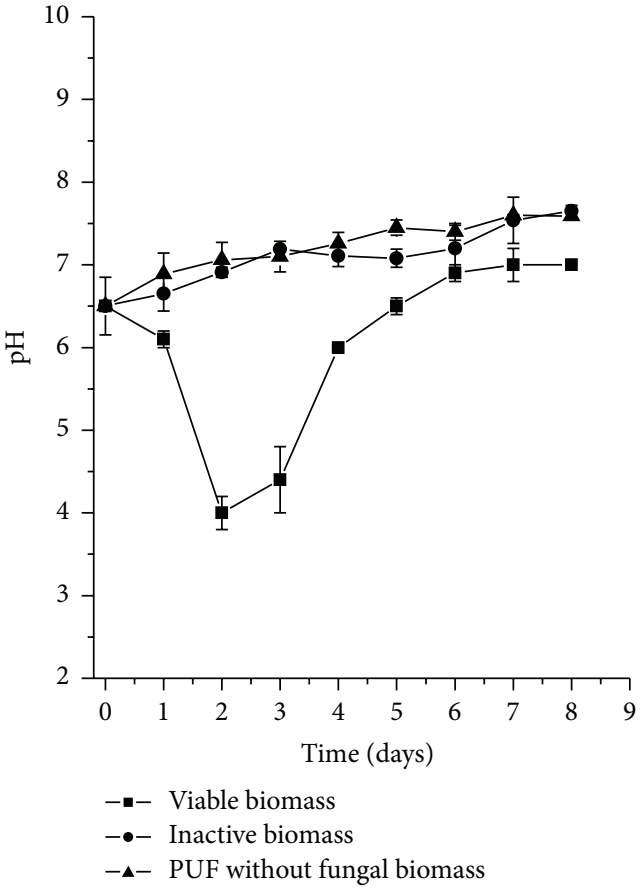

(b)

Figure 7: Glucose consumption (a) and $\mathrm{pH}$ (b) with immobilized T. versicolor, $8 \mathrm{~d}, 25^{\circ} \mathrm{C}, 800 \mathrm{~mL} / \mathrm{min}$ flow air, and nonsterile conditions in bubble column reactor.

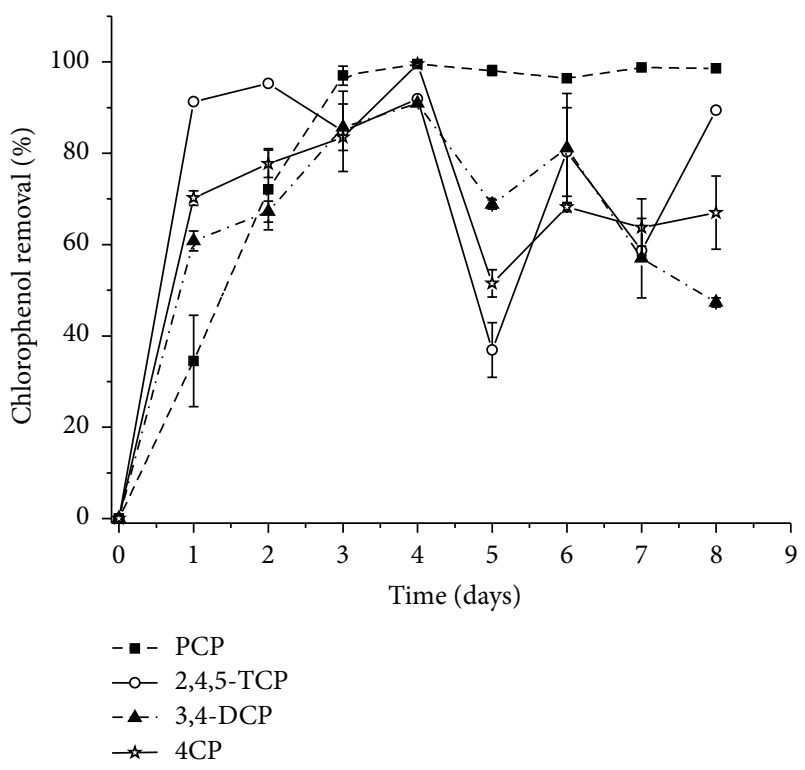

FIGURE 8: Chlorophenols removal with immobilized T. versicolor, $8 \mathrm{~d}, 25^{\circ} \mathrm{C}, 800 \mathrm{~mL} / \mathrm{min}$ flow air, and nonsterile conditions in bubble column reactor.

\section{Conflict of Interests}

The authors declare that they do not have any conflict of interest.

\section{Acknowledgments}

The authors acknowledge the financial support for this work to SEP/CONACYT-48-193, México, DF, México, CINVESTAV, México, DF, México and the University Javeriana, Bogotá, Colombia. The authors would like to recognize the relevant collaboration of Dr. Fernando Esparza García, Dr. Josefina Barrera Córtes, and Dr. Araceli Tomasini Campocosio for providing all precious help and comments during this research in México.

\section{References}

[1] N. Buyukkamaci and E. Koken, "Economic evaluation of alternative wastewater treatment plant options for pulp and paper industry," Science of the Total Environment, vol. 408, no. 24, pp. 6070-6078, 2010.

[2] A. Belém, A. V. Panteleitchouk, A. C. Duarte, T. A. P. RochaSantos, and A. C. Freitas, "Treatment of the effluent from a kraft bleach plant with white rot fungi Pleurotus sajor caju and Pleurotus ostreatus," Global NEST Journal, vol. 10, pp. 426-431, 2008.

[3] S. M. Ghoreishi and M. R. Haghighi, "Chromophores removal in pulp and paper mill effluent via hydrogenation-biological batch reactors," Chemical Engineering Journal, vol. 127, no. 1-3, pp. 59-70, 2007.

[4] A. C. Freitas, F. Ferreira, A. M. Costa et al., "Biological treatment of the effluent from a bleached kraft pulp mill using basidiomycete and zygomycete fungi," Science of the Total Environment, vol. 407, no. 10, pp. 3282-3289, 2009. 
[5] B. Quevedo-Hidalgo, P. C. Narvaéz-Rincón, A. M. PedrozaRodríguez, and M. E. Velásquez-Lozano, "Degradation of chrysanthemum (Dendranthema grandiflora) wastes by Pleurotus ostreatus for the production of reducing sugars," Biotechnology and Bioprocess Engineering, vol. 17, pp. 1103-1112, 2012.

[6] R. Martín-Sampedro, A. Rodríguez, A. Ferrer, L. L. GarcíaFuentevilla, and M. E. Eugenio, "Biobleaching of pulp from oil palm empty fruit bunches with laccase and xylanase," Bioresource Technology, vol. 110, pp. 371-378, 2012.

[7] I. J. Puentes-Cárdenas, A. M. Pedroza-Rodríguez, M. Navarrete-López, T. L. Villegas-Garrido, and E. CristianiUrbina, "Biosorption of trivalent chromium from aqueous solutions by Pleurotus ostreatus biomass," Environmental Engineering and Management Journal, vol. 11, pp. 1741-1752, 2012.

[8] L. Castillo-Carvajal, K. Ortega-González, B. E. BarragánHuerta, and A. M. Pedroza-Rodríguez, "Evaluation of three immobilization supports and two nutritional conditions for reactive black 5 removal with Trametes versicolor in air bubble reactor," African Journal of Biotechnology, vol. 11, pp. 3310-3320, 2012.

[9] L. C. Castillo-Carvajal, A. M. Pedroza-Rodríguez, and B. E. Barragán-Huerta, "Adsorption and biological removal of basic green 4 dye using white-rot fungi immobilized on Agave tequilana weber waste," Fresenius Environmental Bulletin, vol. 22, pp. 2334-2343, 2013.

[10] A. Srinivasan and T. Viraraghavan, "Decolorization of dye wastewaters by biosorbents: a review," Journal of Environmental Management, vol. 91, no. 10, pp. 1915-1929, 2010.

[11] D. Daâssi, H. Zouari-Mechichi, A. Prieto, M. J. Martínez, M. Nasri, and T. Mechichi, "Purification and biochemical characterization of a new alkali-stable laccase from Trametes sp. isolated in Tunisia: role of the enzyme in olive mill waste water treatment," World Journal Microbiology Biotechnology, vol. 29, pp. 2145-2155, 2013.

[12] J. Si, F. Peng, and B. Cui, "Purification, biochemical characterization and dye decolorization capacity of an alkali-resistant and metal-tolerant laccase from Trametes pubescens," Bioresource Technology, vol. 128, pp. 49-57, 2013.

[13] L. M. Henao-Jaramillo, J. A. Fernández-González, B. QuevedoHidalgo, A. E. Florido-Cuellar, and A. M. Pedroza-Rodríguez, "Use of a no conventional biological system and advanced oxidation process with $\mathrm{TiO}_{2} / \mathrm{UV}$ to the discoloration of reactive black 5," International Journal Biotechnology Color, vol. 1, pp. 917, 2012.

[14] J. M. Rosas, M. M. Martínez, A. M. Pedroza, R. Rodríguez, C. Gómez, and D. Nieto, "Estudio del efecto de dos inductores y un protector enzimático sobre la actividad de las enzimas MnP y Lacasa producidas por Trametes versicolor y su efecto en la decoloración de efluentes de la industria papelera," Universitas Scientiarum, vol. 10, pp. 37-45, 2005.

[15] "APHA," in Standard Methods for the Examination of Water and WasteWater, A. E. Greenberg, L. S. Cleceri, and A. D. Eaton, Eds., The American Public Health Association, Washington, DC, USA, 18th edition, 2005.

[16] E. Ríos and G. Calva, "Aplicaciones de la cromatografía de gases y líquidos en Biotecnología," in Aspectos Aplicados de la Biotecnología, pp. 303-354, Politécnico, 1999.

[17] F. C. Michel Jr., S. B. Dass, E. A. Grulke, and C. A. Reddy, "Role of manganese peroxidases and lignin peroxidases of Phanerochaete chrysosporium in the decolorization of kraft bleach plant effluent," Applied and Environmental Microbiology, vol. 57, no. 8, pp. 2368-2375, 1991.

[18] R. Tinoco, M. A. Pickard, and R. Vazquez-Duhalt, "Kinetic differences of purified laccases from six Pleurotus ostreatus strains," Letters in Applied Microbiology, vol. 32, no. 5, pp. 331$335,2001$.

[19] D. C. Montgomery, Diseño y Análisis de Experimentos, Limusa, 2nd edition, 2003.

[20] D. K. Tiku, A. Kumar, R. Chaturvedi, S. D. Makhijani, A. Manoharan, and R. Kumar, "Holistic bioremediation of pulp mill effluents using autochthonous bacteria," International Biodeterioration \& Biodegradation, vol. 64, no. 3, pp. 173-183, 2010.

[21] P. Kaushik and A. Malik, "Fungal dye decolourization: recent advances and future potential," Environment International, vol. 35, no. 1, pp. 127-141, 2009.

[22] V. Elisashvili and E. Kachlishvili, "Physiological regulation of laccase and manganese peroxidase production by white-rot Basidiomycetes," Journal of Biotechnology, vol. 144, no. 1, pp. 3742, 2009.

[23] C. Justino, A. G. Marques, D. Rodrigues et al., "Evaluation of tertiary treatment by fungi, enzymatic and photo-Fenton oxidation on the removal of phenols from a kraft pulp mill effluent: a comparative study," Biodegradation, vol. 22, no. 2, pp. 267-274, 2011.

[24] M. Doyle, Microbiología de los Alimentos. Fundamentos y Fronteras, Acribia, Zaragoza, Spain, 1997.

[25] S. T. Akar, A. Gorgulu, Z. Kaynak, B. Anilan, and T. Akar, "Biosorption of Reactive Blue 49 dye under batch and continuous mode using a mixed biosorbent of macro-fungus Agaricus bisporus and Thuja orientalis cones," Chemical Engineering Journal, vol. 148, no. 1, pp. 26-34, 2009.

[26] Z. Youshuang, Z. Haibo, C. Mingle, W. Zhenzhen, H. Feng, and G. Peiji, "Production of a thermostable metal-tolerant laccase from Trametes versicolor and its application in dye decolorization," Biotechnology and Bioprocess Engineering, vol. 16, no. 5, pp. 1027-1035, 2011.

[27] Y. Guillén and Á. Machuca, "The effect of copper on the growth of wood-rotting fungi and a blue-stain fungus," World Journal of Microbiology and Biotechnology, vol. 24, no. 1, pp. 31-37, 2008.

[28] C. M. Rivera-Hotos, E. D. Morales-Álvarez, R. A. PoutouPiñalez, A. M. Pedroza-Rodríguez, R. Rodríguez-Vázquez, and J. M. Delgado Boada, "Fungal laccases," Fungal Biology Review, 2013.

[29] J. M. Álvarez, P. Canessa, R. A. Mancilla, R. Polanco, P. A. Santibáñez, and R. Vicuña, "Expression of genes encoding laccase and manganese-dependent peroxidase in the fungus Ceriporiopsis subvermispora is mediated by an ACE1-like copper-fist transcription factor," Fungal Genetics and Biology, vol. 46, no. 1, pp. 104-111, 2009.

[30] D. Morales-Fonseca, K. Ruiz-Tovar, M. M. Martínez Salgado et al., "Desarrollo de un biadsorbente laminar con Phanerochaete chrysosporium hipertolerante al cadmio, al níquel y al plomo para el tratamiento de aguas," Revista Iberoamericana de Micología, vol. 27, pp. 111-118, 2010.

[31] H. C. Eisenman and A. Casadevall, "Synthesis and assembly of fungal melanin," Applied Microbiology and Biotechnology, vol. 93, no. 3, pp. 931-940, 2012.

[32] G. Rancaño, M. Lorenzo, N. Molares, S. R. Couto, and M. Á. Sanromán, "Production of laccase by Trametes versicolor in an airlift fermentor," Process Biochemistry, vol. 39, no. 4, pp. 467473, 2003. 
[33] P. A. Karas, C. Perruchon, K. Exarhou, C. Ehaliotis, and D. G. Karpouzas, "Potential for bioremediation of agro-industrial effluents with high loads of pesticides by selected fungi," Biodegradation, vol. 22, no. 1, pp. 215-228, 2011.

[34] N. A. Kulikova, O. I. Klein, E. V. Stepanova, and O. V. Koroleva, "Use of basidiomycetes in industrial waste processing and utilization technologies: fundamental and applied aspects (review)," Applied Biochemistry and Microbiology, vol. 47, no. 6, pp. 565-579, 2011.

[35] D. K. Sahoo and R. Gupta, "Evaluation of ligninolytic microorganisms for efficient decolorization of a small pulp and paper mill effluent," Process Biochemistry, vol. 40, no. 5, pp. 1573-1578, 2005.

[36] T. Rocha-Santos, F. Ferreira, L. Silva et al., "Effects of tertiary treatment by fungi on organic compounds in a kraft pulp mill effluent," Environmental Science and Pollution Research, vol. 17, no. 4, pp. 866-874, 2010.

[37] M. A. Ullah, C. T. Bedford, and C. S. Evans, "Reactions of pentachlorophenol with laccase from Coriolus versicolor," Applied Microbiology and Biotechnology, vol. 53, no. 2, pp. 230234, 2000.

[38] L. F. González, V. Sarria, and O. F. Sánchez, "Degradation of chlorophenols by sequential biological-advanced oxidative process using Trametes pubescens and $\mathrm{TiO}_{2} / \mathrm{UV}$," Bioresource Technology, vol. 101, no. 10, pp. 3493-3499, 2010.

[39] J. Zhang, X. Liu, Z. Xu, H. Chen, and Y. Yang, "Degradation of chlorophenols catalyzed by laccase," International Biodeterioration and Biodegradation, vol. 61, no. 4, pp. 351-356, 2008. 

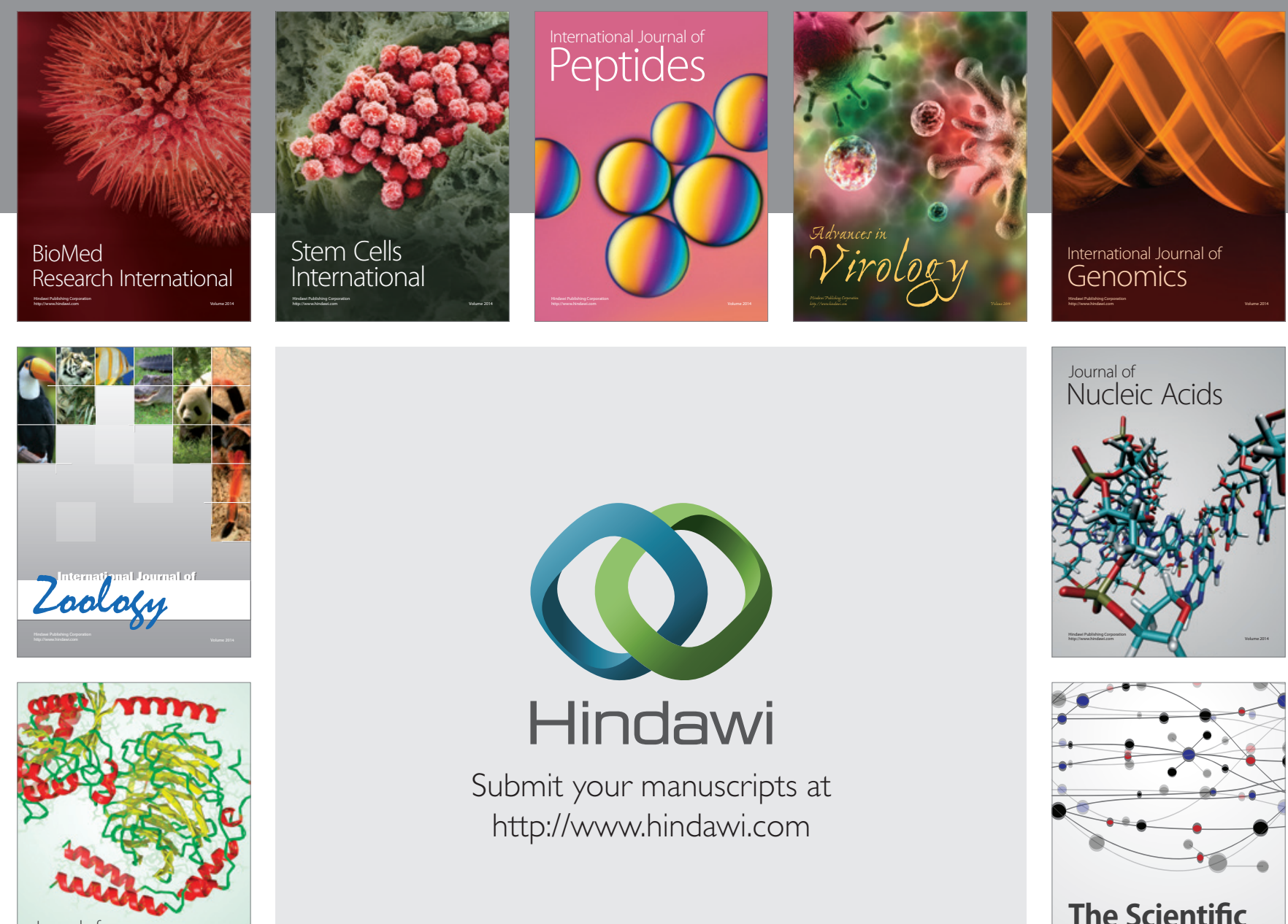

Submit your manuscripts at

http://www.hindawi.com

Journal of
Signal Transduction
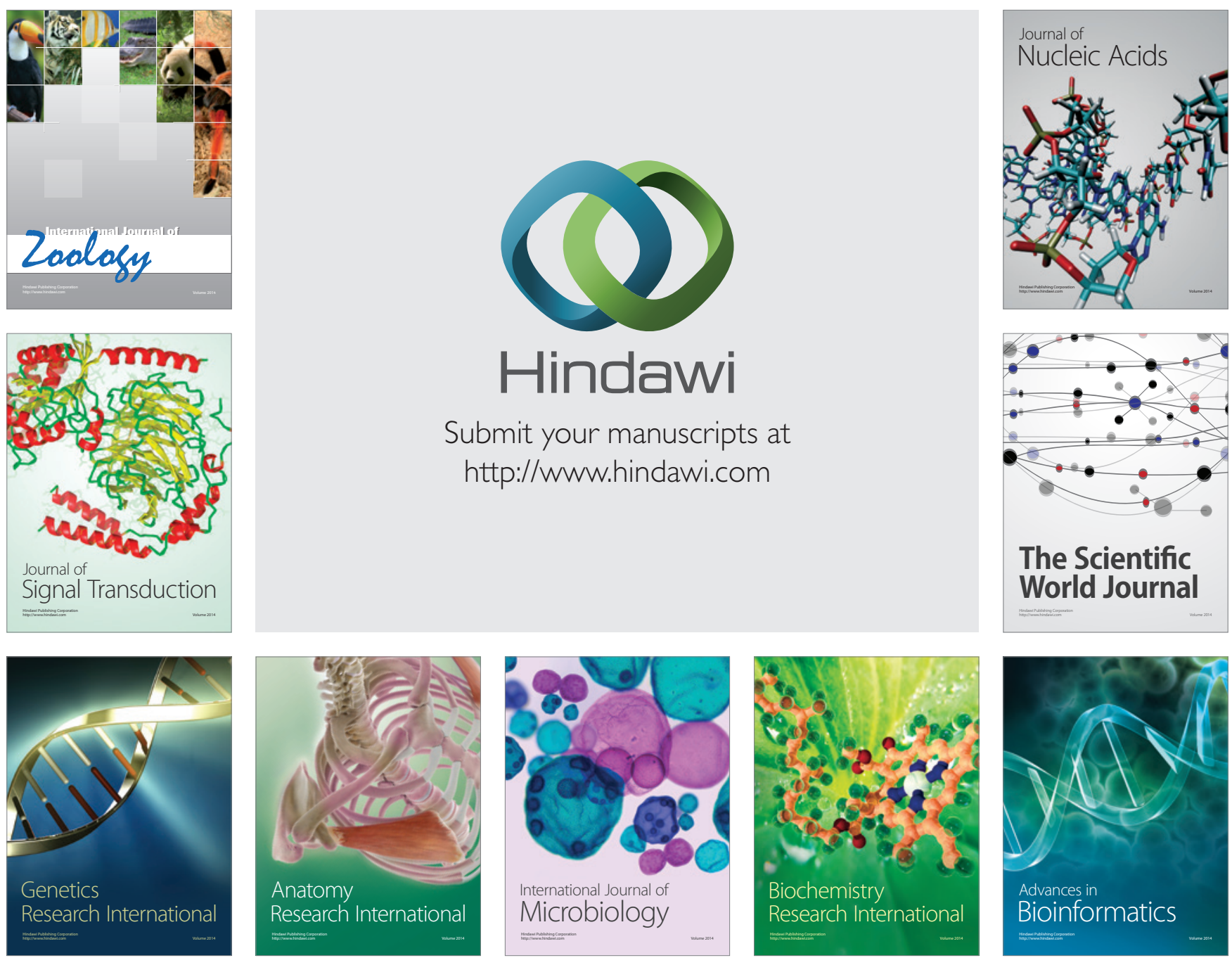

The Scientific World Journal
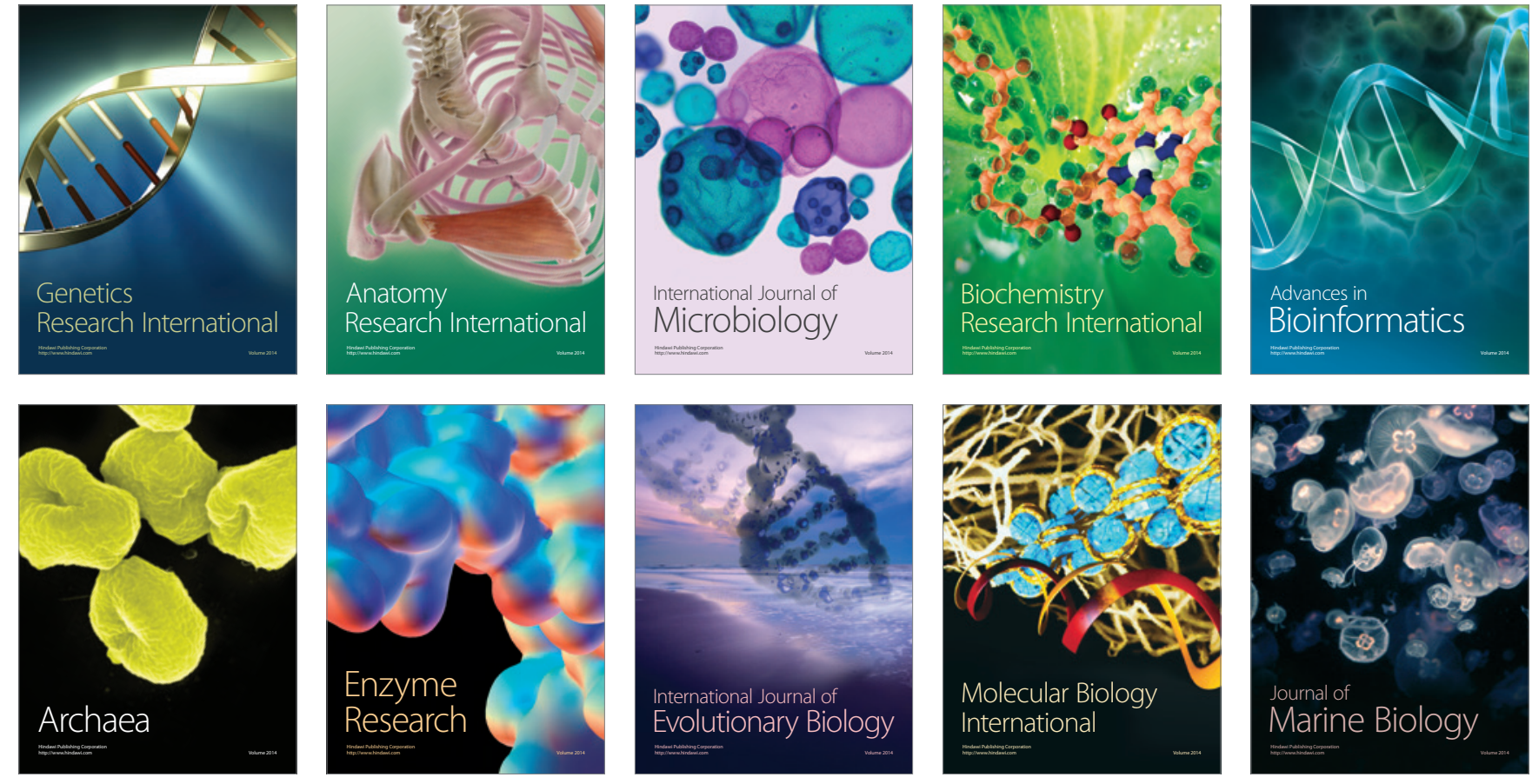